\title{
Distribution of Injected Insulin and Insulin-Antibody Complexes in Normal and Insulin-Immunized Animals*
}

\author{
M.J. Frikke, R.L. Gingerich, P.D. Stranahan, G. Carter, A.K. Bauman, M.H. Greider, \\ P.H. Wright and P.E. Lacy \\ Department of Pharmacology Indiana University School of Medicine Indianapolis, Indiana and Department of Patho- \\ logy Washington University School of Medicine St. Louis, Missouri U.S.A. \\ Received: March 27, 1973, and in revised form: April 17, 1974
}

\begin{abstract}
Summary. The distribution of insulin injected into normal rats and guinea pigs as the free hormone or as insulin-antibody complexes was studied by extraction of immunoreactive insulin and by following the fate of ${ }^{125} \mathrm{I}$ - or ${ }^{191}$ I-labeled insulin in the plasma, liver, kidneys and spleens of the injected animals. Injected free hormone rapidly disappears from the plasma to accumulate transiently in the liver, and, to a greater extent, in the proximal convoluted tubules of the kidneys. When insulin-antibody complexes formed in vitro are injected, the hormone disappears more slowly from the plasma and concentrates in the liver and spleen where it can be
\end{abstract}

demonstrated by autoradiography in reticulo-endothelial cells; little or none is found in the kidneys. After injection into insulin-immunized guinea pigs, the hormone disappears very slowly from the plasma and accumulates almost exclusively in the liver with no evidence of concentration by any particular cell type; little or none is found in the kidneys or spleen.

Key words: Insulin, insulin-antibody complexes, rat, guinea pig, insulin-immunized guinea pigs, insulin distribution, reticulo-endothelial system.
Several tissues, and particularly the liver [9] and kidneys [16], play roles in the utilization of secreted or injected insulin in normal animals and man. Little is known, however, of how this normal process may be affected by the presence of insulin antibodies which appear in the plasma of all animals and human subjects treated with the hormone [6]. In the present study normal and insulin-treated animals were injected intra. vascularly with radio-iodinated or unlabeled insulin to show that such antibodies, whether homologous or heterologous, have a marked effect upon insulin utilization, an effect which still requires delineation and explanation.

\section{Materials and Methods}

\section{Insulin}

Unlabeled porcine insulin (Lot Nos. PJ5589, 21.1 $\mathrm{U} / \mathrm{mg}$, and PJ5632, $23.9 \mathrm{U} / \mathrm{mg}$; Eli Lilly and Company, Indianapolis, Indiana) was stored at 0 to $4^{\circ} \mathrm{C}$ as a stock solution $(100 \mathrm{U} / \mathrm{ml})$ in dilute acetic acid $(0.6 \%, \mathrm{w} / \mathrm{v})$; these were crystalline zinc-insulin preparations. Solutions containing ${ }^{125}$ I-labeled porcine insutin $(110-120 \mathrm{mC} . \mathrm{mg}, 0.8-1.0 \mu \mathrm{g} / \mathrm{ml}$; Cambridge Nuclear Corporation, Cambridge, Mass.) were obtained commercially, diluted upon receipt in $3 \%$ NGPS (see below) and stored in the frozen state $\left(-10^{\circ} \mathrm{C}\right)$ for a maximum of one month; samples used for injections were used within 3 days of receipt without dilution and

* This investigation was supported by Grant Nos. AM 13237, AM 01226 and ES 00128 from the U.S. Public Health Services. storage. Stock solutions were appropriately diluted for injection or assay purposes immediately before use.

\section{Guinea Pig Sera}

Normal serum (NGPS) was obtained commercially (Hyland Laboratories, Los Angeles, California). Antiinsulin sera (GPAIS) were obtained from guinea pigs immunized with bovine (Lot No. 524, binding $1.5 \mathrm{U}$ insulin $/ \mathrm{ml}$ ) or porcine (Lot No. 551, binding $1.5 \mathrm{U}$ insulin $/ \mathrm{ml}$ ) insulin by methods described in detail elsewhere [22]. All sera were stored in the frozen state $\left(-10^{\circ} \mathrm{C}\right)$ and thawed for dilution immediately before use.

\section{Inocula}

Labeled and/or unlabeled insulins in relatively small volumes of buffer ( $3 \%$ NGPS) or normal serum (NGPS) were added in appropriate amounts to NGPS or GPAIS and allowed to stand at room temperature $\left(23\right.$ to $\left.28^{\circ} \mathrm{C}\right)$ for 30 to $60 \mathrm{~min}$. The resulting solutions $(0.5$ or $1.0 \mathrm{ml})$ contained sufficient TCA-precipitable radioactivity (ca $8.3 \times 10^{6} \mathrm{cpm} /$ inoculum) to get conveniently measurable radioactivity in the plasma, livers and spleens after injection. Of the total radioactivity contained in these inocula, the TCA-precipitable portion accounted for $87 \%$ (rats) or $95 \%$ (guinea pigs); these figures closely approximate to the proportions of labeled material bound by an excess of GPAIS and are therefore assumed to reflect the immuno-reactive contents.

\section{Animals}

Normal rats (male, 180-225 g body wt) and guinea pigs (male, $800-1200 \mathrm{~g}$ body wt) were fed on standard 
diets and used in the fully fed state. Insulin-immunized guinea pigs had received 8 subcutaneous injec. tions of bovine insulin over a period of six months; the method of immunization has been described [22]. One week before they wore used, their sera bound 0.9 to 4.4 Units porcine insulin $/ \mathrm{ml}$ (Mean, $2.1 \pm 0.2 \mathrm{U} / \mathrm{ml}$ ).

\section{Experimental Procedures}

Rats were each injected intravenously (tail vein) with the same volume $(1.0 \mathrm{ml})$ of inoculum and killed at timed intervals up to $90 \mathrm{~min}$ later. All guinea pigs were first injected subcutaneously with an antihistamine (Chlorphenyramine maleate, Chlortrimeton, 10 mg; Schering Corporation, Bloomfield, New Jersey) and then lightly anesthetized with ether. Approximately $15 \mathrm{~min}$ later the inoculum $(0.5 \mathrm{ml})$ was injected into the heart, the animals being killed by decapitation 10 or $30 \mathrm{~min}$ later. Blood was collected from the severed necks of all animals into heparinized beakers and the plasma separated rapidly by centrifugation. The livers, spleens and kidneys were removed rapidly and weighed portions or the whole organs examined as follows:

a. Radioactive Contents. Samples of plasma $(01 \mathrm{ml})$ were diluted in $3 \%$ NGPS $(0.4 \mathrm{ml})$ and weighed aliquots of the tissues (ca. $1.0 \mathrm{~g}$ ) were homogenized (Polytron, Kinematica GMBH, Lucerne, Switzerland) in distilled water $(10 \mathrm{ml})$. Aliquots $(0.5 \mathrm{ml})$ of these diluted or homogenized samples were assayed for total gammaradioactive content. TCA-precipitable radioactivity was determined after treatment of each aliquot $(0.5 \mathrm{ml})$ with an equal volume of trichloracetic acid $(0.5 \mathrm{ml}$; $20 \%, \mathrm{w} / \mathrm{v})$, washing of the precipitate with TCA $(1.0 \mathrm{ml}, 10 \%, \mathrm{w} / \mathrm{v})$, and removal of the supernatant solution. The gamma-radioactive contents of these solutions, suspensions and precipitates were measured in a well-type scintillation counter (Series 300, Model 5052; Packard Instrument Company, LaGrange, Illinois), the periods of counting, except when negligible radioactivity was detectable, being sufficient to obtain at least 5000 counts per sample.

b. Immuno-reactive Insulin Contents. Plasma and weighed aliquots of liver and kidney from rats injected with inocula containing only unlabeled porcine insulin were extracted with acid-alcohol (10 vols, $w$ or $\nabla / v)$ and the extracts neutralized with a saturated solution of sodium bicarbonate; details of the method have been described [21]. The insulin contents of these neutralized extracts were measured by immunoassay [11]. Briefly, all reagents used in the assay were dissolved in a buffered solution $\left(\mathrm{Na}_{2} \mathrm{HPO}_{4} / \mathrm{KH}_{2} \mathrm{PO}_{4}, 0.05\right.$ $\mathrm{M}, \mathrm{pH} 7.0)$ containing sodium chloride $(0.4 \%, \mathrm{w} / \mathrm{v})$ and NGPS $(3 \%, v / v)$; this buffered solution is here termed $3 \%$ NGPS. The neutralized tissue and plasma extracts (5 to $20 \mu \mathrm{L} / 0.1 \mathrm{ml} 3 \% \mathrm{NGPS}$ ) and appropriate solutions of porcine insulin ( 0 to $120 \mu \mathrm{U} / 0.1 \mathrm{ml} 3 \% \mathrm{NGPS}$ ) were each pre-incubated for $60 \mathrm{~min}$ at $36^{\circ} \mathrm{C}$ with GPAIS (20 $\mu \mathrm{L}$ Lot $524 / 0.2 \mathrm{ml} \mathrm{3 \%}$ NGPS), and then incubated for $30 \mathrm{~min}$ at room temperature (ca. $25^{\circ} \mathrm{C}$ ) with a mixture of unlabeled $(350 \mu \mathrm{U})$ and ${ }^{125} \mathrm{I}$-labeled (ca. $10 \mu \mathrm{U}$ ) porcine insulin in $3 \%$ NGPS $(0.1 \mathrm{ml})$. Control tubes containing an excess or no GPAIS were similarly treated. Antibody-bound labeled insulin was precipitated with alcohol $(1.6 \mathrm{ml}, 95 \%, \mathrm{v} / \mathrm{v})$ and the precipitates washed once with more dilute alcohol $(2.0 \mathrm{ml} ; 76 \%, \nabla / \mathrm{v})$ before counting.

c. Autoradiography. Tissues (liver, kidney, spleen etc.) were rapidly removed after death from rats and guinea pigs injected with labeled insulin and fixed at room temperature for $24 \mathrm{~h}$ in $10 \%$ neutral buffered formalin. The fixed tissues were dehydrated and embedded in paraffin. Sections (thickness, $5 \mu$ ) were coated with Kodak NTD emulsion and stored at $4^{\circ} \mathrm{C}$. Separate sets of slides were developed one, two and three weeks after coating or, in other words, 28,35 and 42 days after the injections. The sections were then stained with hematoxylin and eosin for microscopic examination.

\section{Expression of Results}

The radioactive contents of plasma and of individual tissues are expressed as percentages (Mean \pm SEM) of the TCA-precipitable radioactive contents of the inocula injected into rats and guinea pigs. To determine the radioactive contents of the plasma compartment, it was assumed that the plasma volume of rats is equal to the volume of distribution of radio-iodinated albumin one minute after its intravenous injection. The volume found during preliminary studies in a group of 4 rats $(4.37 \pm 0.15 \mathrm{ml} / 100 \mathrm{~g}$ body $\mathrm{wt}$ ) was not significantly different from that $(4.30 \pm 0.13 \mathrm{ml} / 100 \mathrm{~g}$ body wt) reported previously in a much larger group $(n=14)$ of normal rats two minutes after injection [23]. The plasma volume of guinea pigs was assumed to be $3.94 \mathrm{ml} / 100 \mathrm{~g}$ body wt [13]. Unless otherwise stated, the quoted radioactive contents of plasma and tissues refer to TCAprecipitable material found in them and presumed to represent unchanged insulin. The immuno-reactive insulin contents of livers and kidneys from rats injected with unlabeled insulin are expressed as percentages (Mean $\pm S E M$ ) of the amount injected. All statistical analyses were carried out by methods described by Snedecor and Cochran [17].

\section{Results}

\section{Fate of Labeled Insulin Injected into Normal Rats}

In one study, normal fully fed conscious rats (Mean body wt, $198+1.7 \mathrm{~g}$ ) were injected intravenously with pre-incubated solutions $(1.0 \mathrm{ml})$ containing ${ }^{125} \mathrm{I}$ labeled (ca. $0.7 \mathrm{mU}$ ) and unlabeled $(10.0 \mathrm{mU})$ porcine insulin in either (a) NGPS $(0.90 \mathrm{ml}$ ) or (b) an excess of GPAIS (Lot No. $551,0.90 \mathrm{ml}$ ). The animals were killed by decapitation at intervals up to $90 \mathrm{~min}$ after injection.

As shown in Fig. 1, TCA-precipitable radioactivity rapidly disappeared from the plasma in animals given inocula containing no antibodies (open circles); less 
than $10 \%$ could be recovered after $10 \mathrm{~min}$. Recovery from the livers of these animals never exceeded $10 \%$, little or none being found after $15 \mathrm{~min}$. By contrast, TCA-precipitable radioactivity in the plasma of rats injected with insulin which had previously been allowed to react with antibodies (closed circles) decreased more slowly; more then $10 \%$ of the inoculum was still present in the plasma after $90 \mathrm{~min}$. Recovery of labeled material in the livers of these animals increased rapidly, more than $40 \%$ of the inoculum being recovered at all times between 10 and 70 min after injection. The livers and spleens of these animals were not examined for radioactive contents but they and the livers were examined by autoradiography (see below).

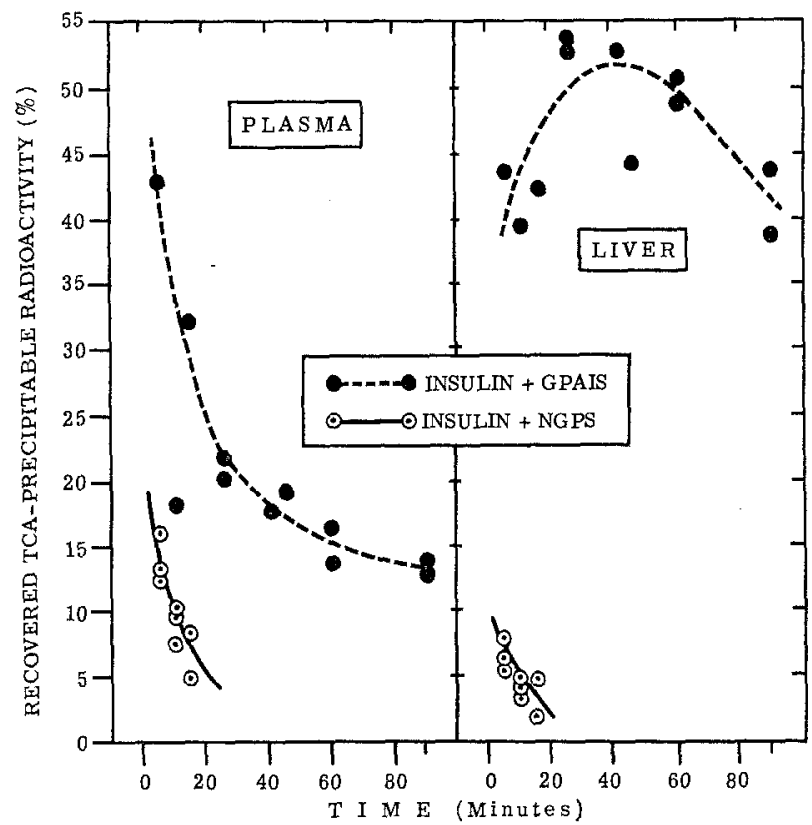

Fig. 1. Recovery in TCA-precipitable form of ${ }^{125} \mathrm{I}$-labeled insulin (ca. $0.6 \mathrm{mU}$ ) mixed with unlabeled insulin (ca 1.0 U) and incubated before injection with NGPS (open circles) or GPAIS (closed circles). Each point represents recovery from the liver or plasma of single animals killed 5 to 85 min after injection

Fate of Labeled Insulin Injected into Normal and Insulin-Immunized Guinea Pigs

All guinea pigs, whether normal (Mean body wt, $922 \pm 28 \mathrm{~g}$ ) or insulin-immunized (Mean body wt, $1022 \pm 42 \mathrm{~g}$ ), were injected with the same volume of preincubated solution $(0.5 \mathrm{ml})$ containing the same mixture of ${ }^{125}$ I-labeled (ca. $2.3 \mathrm{mU}$ ) and unlabeled (ca. $200 \mathrm{mU})$ porcine insulins and either (a) NGPS $(0.38 \mathrm{ml})$, or (b) an excess of GPAIS $(0.39 \mathrm{ml})$. The animals were killed by decapitation either 10 or 30 min after injection.

As shown in Table 1, little $(9 \%)$ of the insulin injected in the absence of antibodies could be recovered from the plasma of normal guinea pigs after $10 \mathrm{~min}$, more having by then accumulated in the livers $(20 \%)$ and kidneys (15\%). Expressed in terms of concentration of radioactivity in these tissues, those found in the liver $(124 \mathrm{cpm} / \mathrm{g})$ and kidney $(603 \mathrm{cpm} / \mathrm{g})$ were higher than that present in plasma $(54 \mathrm{cpm} / \mathrm{ml})$. Almost no radioactive material was found in the spleen. When normal guinea pigs were killed $30 \mathrm{~min}$ after injection of insulin which had been pre-incubated with antibodies, much more of the inoculum (21\%) was recovered in the plasma, most of the remainder being found in the liver $(68 \%)$; very little appeared in the kidneys or spleen. In this case, the concentrations of radioactive material in the liver $(444 \mathrm{cpm} / \mathrm{g})$ and spleen $(211 \mathrm{cpm} / \mathrm{g})$ exceeded that in the plasma $(108 \mathrm{cpm} / \mathrm{ml})$ and little could be found in the kidneys $(15 \mathrm{cpm} / \mathrm{g})$.

After injection of labeled insulin in the absence of antibodies into insulin immunized guinea pigs much of the inoculum was recovered in TCA-precipitable form from the plasma after $10(59 \%)$ and $30(43 \%) \mathrm{min}$. Meanwhile there was a corresponding increase in recovery from the liver between $10(45 \%)$ and $30(63 \%)$ min. Little radioactivity could be found in either the kidneys or spleen at either time of killing. Relative to the concentrations of radioactive materials found in the plasma after $10(326 \mathrm{cpm} / \mathrm{ml})$ and $30(212 \mathrm{spm} / \mathrm{ml})$ minutes, that in the liver was equal after $10 \mathrm{~min}$ $(301 \mathrm{cpm} / \mathrm{g})$ and much greater after $30 \mathrm{~min}(405 \mathrm{cpm} / \mathrm{g})$. Concentrations of radioactivity in the kidneys and spleens were much lower than that in the plasma at both times of killing.

\section{Autoradiography of Tissues from Animals Injected with Labeled Insulin}

In sections of tissues taken from normal rats and guinea pigs the same distributions of radioactive granules were observed. Thus after injection of labeled insulin in the absence of antibodies, radioactive granules were concentrated over the cytoplasm of cells lining the proximal convoluted tubules of the kidneys; a typical example is shown in Fig. $2 \mathrm{~A}$. No radioactive grains were seen to have concentrated over any particular cell type either in the liver (Fig. 2B) or spleen. After injection of labeled insulin which had been previously allowed to react with anti-insulin serum in vitro, radioactive granules were found to have localized over reticular macrophages in the liver (Fig. 2C) and spleen (Fig. 2D), but no specific localization was seen in the kidneys. After injection of labeled insulin in the absence of antibodies into insulin-immunized guinea pigs, some localization of radioactive granules was seen over reticular macrophages in the spleen. In the liver, however, the granules were diffusely distributed in the vascular sinusoidal spaces with no evidence of particular cellular localization (Fig. 2 F). No radioactive granules were found in the kidneys.

\section{Fate of Unlabeled Insulin Injected into Normal Rats}

Groups of 4 to 6 normal rats (Mean body wt, 201 土 $2.7 \mathrm{~g})$ were injected intravenously with pre-incubated solutions $(1.0 \mathrm{ml})$ containing unlabeled porcine insulin 
(ca. 1.0 Unit) in either (a) NGPS $(0.90 \mathrm{ml})$ or (b) a slight excess of GPAIS (Lot No. $551 ; 0.90 \mathrm{ml}$ ). The animals were killed by decapitation at intervals up to 90 min later. were consistently high (79 to $96 \mathrm{mU} / \mathrm{g}$ ) while those found in the kidneys, with one exception after $10 \mathrm{~min}$ (107 $\mathrm{mU} / \mathrm{g}$ ), were low (5 to $13 \mathrm{mU} / \mathrm{g}$ ). The spleens and plasma of these animals were not examined.

Table 1. Recovery of ${ }^{\mathbf{1 2 5}}$ I-labeled porcine insulin injected into normal and immune guinea pigs

\begin{tabular}{|c|c|c|c|c|c|c|}
\hline \multirow{2}{*}{$\begin{array}{l}\text { Animal } \\
\text { group }\end{array}$} & \multirow{2}{*}{ Inoculum } & \multirow{2}{*}{$\begin{array}{l}\text { Time } \\
\text { killed } \\
\text { (min) }\end{array}$} & \multicolumn{4}{|c|}{ Tissue analyzed } \\
\hline & & & Plasma & Liver & Kidneys & Spleen \\
\hline \multirow{4}{*}{ Normal } & \multicolumn{6}{|c|}{ (a) Recovered radioactivity (\%) } \\
\hline & Ins & 10 & $9.4 \pm 0.3$ & $19.7 \pm 1.2$ & $14.7 \pm 1.0$ & 0.1 \\
\hline & $\operatorname{Ins} / \mathrm{Ab}$ & 30 & $20.5 \pm 1.3$ & $68.0 \pm 2.0$ & 0.4 & 0.9 \\
\hline & Ins & 10 & $59.4 \pm 9.8$ & $44.7 \pm 3.2$ & 0.6 & 0.3 \\
\hline Immune & Ins & 30 & $43.1 \pm 5.4$ & $62.5 \pm 3.4$ & 0.5 & 0.3 \\
\hline \multirow{3}{*}{ Normal } & \multicolumn{6}{|c|}{ (b) Tissue radioactivity (Counts/g) } \\
\hline & Ins & 10 & $54 \pm 3$ & $124 \pm 8$ & $603 \pm 47$ & $28 \pm 3$ \\
\hline & $\operatorname{Ins} / \mathrm{Ab}$ & 30 & $108 \pm 4$ & $444 \div 46$ & $15 \pm 1$ & $211 \pm 24$ \\
\hline \multirow{2}{*}{ Immune } & $\operatorname{Ins}$ & 10 & $326 \pm 53$ & $301 \pm 37$ & $23 \pm 3$ & $75 \pm 9$ \\
\hline & Ins & 30 & $212 \pm 18$ & $405 \pm 18$ & $16 \pm 1$ & $59 \pm 10$ \\
\hline
\end{tabular}

Table 1. Groups $(n=5)$ of normal and insulin-immunized guinea pigs were injected (intracardiac) with a solution $\left(0.5 \mathrm{ml}\right.$ ) containing ${ }^{125}$ I-labeled (ca $2.3 \mathrm{mU}$ ) and unlabeled (ca $200 \mathrm{mU}$ ) porcine insulin in NGPS (Ins) or in GPAIS (Ins/Ab). Shown in the Table are the mean values ( \pm SEM) for (a) the proportions (\%) of injected radioactive material recovered in TCA-precipitable form from the plasma, liver, kidneys and spleen and (b) the tissue radioactivity (Counts/g tissue) in each tissue.

Table 2. Recovery of immunoreactive porcine insulin injected into normal rats

\begin{tabular}{|c|c|c|c|c|c|c|}
\hline \multirow{2}{*}{$\begin{array}{l}\text { Tissue } \\
\text { Nature }\end{array}$} & \multirow[b]{2}{*}{ Weight $(g)$} & \multicolumn{5}{|c|}{ Recovered immunoreactive insulin (\%) } \\
\hline & & $5 \mathrm{~min}$ & $10 \mathrm{~min}$ & $30 \mathrm{~min}$ & $50 \mathrm{~min}$ & $90 \min$ \\
\hline \multicolumn{7}{|c|}{ (a) Insulin in NGPS } \\
\hline Liver & $7.76 \pm 0.3$ & $14.9 \pm 4.4$ & $24.5 \pm 4.2$ & $11.3 \pm 1.5$ & $5.2 \pm 1.0$ & $2.9 \pm 0.1$ \\
\hline Kidneys & $1.65+0.1$ & $19.6 \pm 3.2$ & $44.2 \pm 1.7$ & $9.9 \pm 0.6$ & $4.9 \pm 0.3$ & $1.2 \pm 0.1$ \\
\hline Animals & 23 & 4 & 4 & 5 & 6 & 4 \\
\hline \multicolumn{7}{|c|}{ (b) Insulin in GPAIS } \\
\hline Liver & $8.36 \pm 0.3$ & $66.5 \pm 1.7$ & $80.2 \pm 2.3$ & $66.9 \pm 3.6$ & $70.9 \pm 4.9$ & $43.1 \pm 4.9$ \\
\hline Kidneys & $1.70 \pm 0.1$ & $0.8 \pm 0.4$ & $18.3 \pm 1.3$ & $1.8 \pm 0.6$ & $2.2 \pm 0.3$ & $0.6 \pm 0.3$ \\
\hline Animals & 23 & 4 & 4 & 5 & 6 & 4 \\
\hline
\end{tabular}

Table 2. Groups of normal fed rats (4 to 6 ) were injected intravenously with unlabeled porcine insulin (ca $1.0 \mathrm{U}$ ) in the same volume $(1.0 \mathrm{ml})$ of (a) NGPS and (b) GPAIS. Shown in the Table are the mean values ( \pm SEM) for the weights of the organs assayed and the proportions ( $\%$ ) of injected unlabeled insulin recovered in immunoreactive form from the livers and kidneys, the numbers of animals used under each experimental condition, and the times after injection $(\mathrm{min})$ at which they were killed.

As shown in Table 2, insulin injected in the absence of antibodies was mainly recovered from the kidneys, a peak rate $(44 \%)$ being observed after $10 \mathrm{~min}$. Smaller amounts appeared in the liver during the first $10 \mathrm{~min}$. The concentration of insulin found after $10 \mathrm{~min}$ in the kidneys (268 $\mathrm{mU} / \mathrm{g}$ ) was much greater than that found in the livers $(32 \mathrm{mU} / \mathrm{g})$. After neutralization with a slight excess of anti-insulin serum in vitro injected unlabeled insulin rapidly accumulated in the liver, more than $60 \%$ of the injected dose being recovered at periods from 5 to $50 \mathrm{~min}$ after injection. During this period, concentrations of insulin found in the livers

\section{Discussion}

The observations outlined above confirm previously published reports of the fate of radio-iodinated insulin injected into normal animals. Thus, as reported by others including Izzo et al. [9], labeled insulin rapidly disappears from the plasma of normal rats and guinea pigs to accumulate transiently in the livers and kidneys (Table 1, Fig. 1). Within the liver no particular type of cell appeared to concentrated labeled material in the present studies (Fig. 2B) and the reports of others are contradictory. Thus parenchymal cells [10], Kupffer 
cells [1], both [20] and neither [18] of these hepatic cell types have been reported to accumulate injected labeled insulin in normal animals. In the kidneys, as uniformly reported elsewhere $[1,10,20]$, labeled in- derived from endogenous sources but it is clear from the results shown in Table 2 that unlabeled as well as labeled insulin concentrates transiently in both the livers and kidneys of normal rats. This pattern of in-
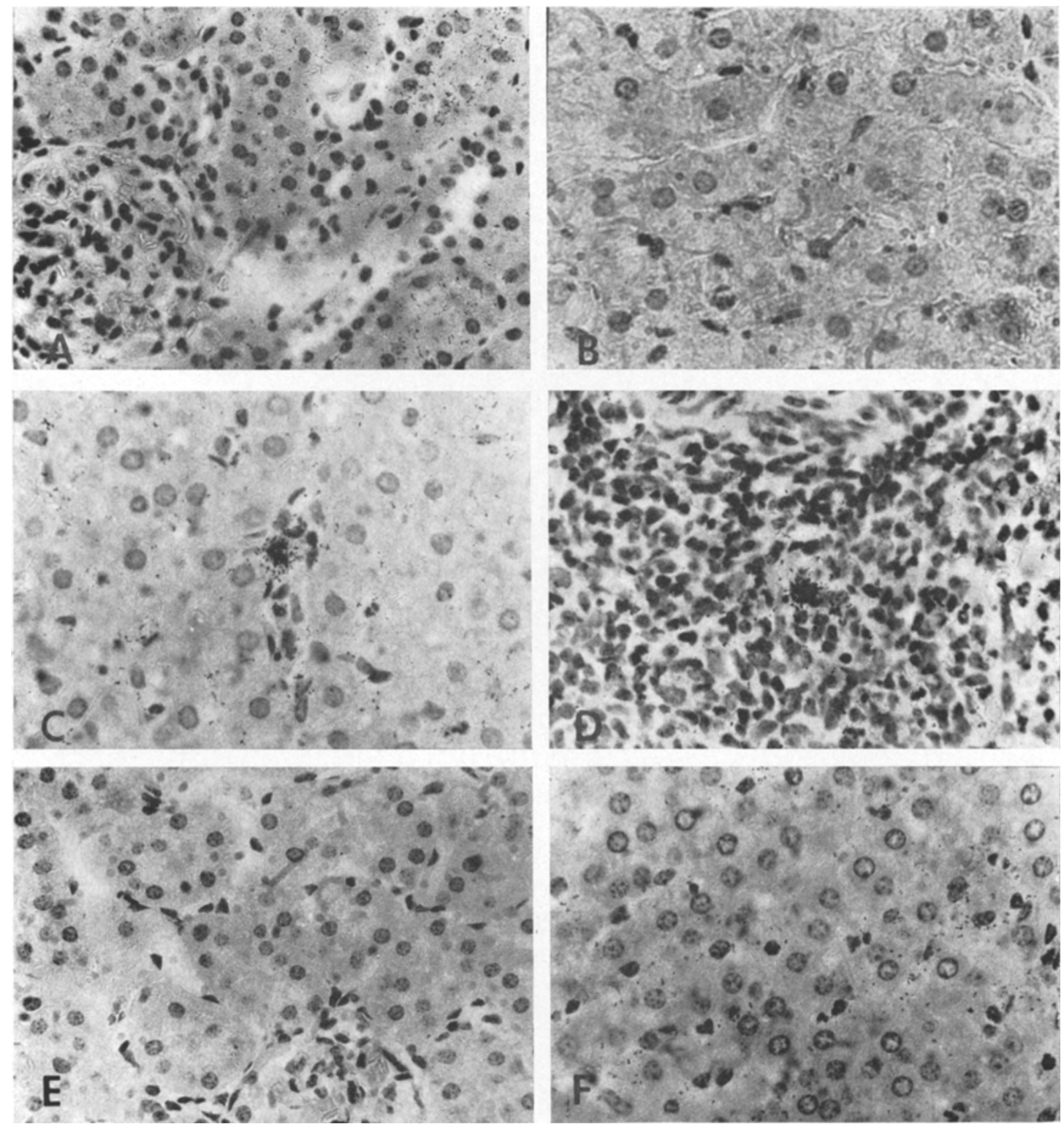

Fig. 2. Autoradiographs of tissue sections obtained from normal and immune guinea pigs injected with ${ }^{125} \mathrm{I}-\mathrm{labeled}$ insulin in NGPS or GPAIS; experimental details are shown in Table 1 and in the text. Sections (X 200-400), which were stained with hematoxylin and eosin for microscopic examination, were obtained from (A) the kidney and (B) liver of a normal guinea pig injected with labeled insulin in NGPS and killed after 10 min; from (C) the liver, (D) spleen and (E) kidney of normal guinea pigs injected with labeled insulin in GPAIS and killed after $30 \mathrm{~min}$; and from (F) the liver of an insulin-immunized guinea pig injected with labeled insulin in NGPS and killed after 30 min

sulin concentrates in the lumen and cells lining the walls of the convoluted tubules (Fig. $2 \mathrm{~A}$ ). Less attention has been paid to the fate of unlabeled insulin in normal animals and part of the immuno-reactive insulin recovered in the present studies might have been sulin utilization by the normal animal has yet to be defined in detail but it is grossly disturbed by the presence of antibodies to insulin.

Normal animals such as mice [2] and dogs [24] have been injected with radioiodinated insulin which has 
previously been allowed to react in vitro with antibodies to insulin produced by the guinea pig. Under these conditions the labeled hormone did not accumulate in the kidneys but concentrated rapidly in the liver, observations confirmed and extended in the present studies. In both normal rats (Fig. 1) and guinea pigs (Table 1), radio-iodinated insulin which had previously been neutralized in vitro with an excess of guinea pig anti-insulin serum did not accumulate in the kidneys but did concentrate in the liver in TCA-pre. cipitable form; its disappearance from the plasma was also retarded. When unlabeled insulin was injected into normal rats after neutralization with a slight excess of guinea pig anti-insulin serum, a significant proportion of injected immunoreactive hormone $(18.3 \%)$ was recovered from the kidney at only one time (10 $\mathrm{min})$, more than half of the injected dose accumulating in the liver within $5 \mathrm{~min}$ and persisting for over $50 \mathrm{~min}$ (Table 2). Part of this recovered immunoreactive insulin could have been derived from the injected rat's pancreas but the proportion was probably only small since most of the injected antibodies had been neutralized with exogenous insulin before injection. It should also be noted (Table 1 ) that after injection into normal guinea pigs, complexes formed with homologous antibodies by labeled insulin concentrate in the spleen to levels higher than those found simultaneously in the plasma and comparable with hepatic concentrations; this has also been observed (unpublished) in rats injected with the same (heterologous) labeled complexes. By autoradiography it was further shown that in these animals the labeled material had concentrated in macrophages of the liver and spleen (Fig. 2C and D), a finding which strongly suggests that injected insulin/ antibody complexes formed in vitro are, in part at least, removed from the circulation by cells of the reticulo-endothelial system. The fate of insulin injected into insulin-immunized animals is less definite.

It has long been known, and is confirmed here (Table 1), that labeled insulin disappears at an abnormally slow rate from the plasma of human subjects $[7,19]$ and guinea pigs [8] which have previously been treated or immunized with insulin. The present studies further show that the injected labeled hormone does not accumulate in the kidney but concentrates progressively in the liver (Table 1); no accumulation was ever observed in the spleen. On autoradiography and in complete contrast to what was found in normal animals injected with complexes formed in vitro, concentration of labeled material was not demonstrated within any particular cell type in the liver. This discrepancy has yet to be explained but it is clear that whether the antibodies are homologous or heterologous, they do radically alter the fate of exogenous insulin.

At this stage of our knowledge of reactions between insulin and its antibodies, it is not possible to give an adequate explanation of these experimental phenomena. Other antigens which form insoluble antigen/ antibody complexes are rapidly removed from the circulation of injected animals by reticulo-endothelial cells [3] and there is now evidence to suggest that some soluble complexes may be removed rapidly if the ratio of antibody to antigen in those complexes exceeds $2: 1$ [12]. Although Berson and Yalow have long claimed that insulin only forms soluble complexes and is a monovalent antigen [5], there is well documented evidence that it can form insoluble complexes in vitro with anti-insulin sera from a variety of species including the guinea pig [15]. It has also been established that insulin can exist in solution in a dimeric form [14] and so even if it is monovalent in the monomeric form it could form complexes in solution which have high ratios of antibody to antigen. There are therefore some reasonable theoretical grounds for believing that insulin, like other antigens, could be metabolized by some well recognized immunological mechanism when antibodies are present and that the present observations could be explained on this basis. There is also the possibility that this abnormal process could in some way be responsible for the extreme resistance to insulin therapy which is seen in a small proportion of resistant diabetics. As Berson and Yalow [4] suggested many years ago, "owing to its degradation with antibody, a large fraction of the bound (injected) insulin may never become available to the tissues" in these patients. Until more is known of the compositions and properties of insulin/antibody complexes and of their disposal in immune species, observations such as those presented here can provide only suggestive evidence in support of such hypotheses.

Acknowledgements. The authors wish to acknowledge the skilled technical assistance of Mrs. Lois Grawe and Mrs. Valerie Steinberg in the preparation of tissues for light microscopy and autoradiography; and Miss Jean Posey, Miss Mary Posey and Mr. L.L. Norman in the analyses of tissues for radioactive and insulin contents.

\section{References}

1. Beck, L.V., Fedynskyj, N.: Evidence from combined immunoassay and radioautography procedures that intact insulin- ${ }^{125} \mathrm{I}$ molecules are concentrated by mouse kidney proximal tubule cells. Endocrinology $81,475-485(1967)$

2. Beck, L. V., Zaharko, D.S., Roberts, N., King, C.: On insulin-I ${ }^{131}$ metabolism in mice. Modifying effects of anti-insulin serum and of total insulin dosage. Diabetes 15, 336-341 (1966)

3. Benacerraf, B., Sebestyen, M., Cooper, N.S.: The clearance of antigen antibody complexes from the blood by the reticulo-endothelial system. J. Immunol. 82, $131-137$ (1959)

4. Berson, S.A., Yalow, R.S.: Insulin antagonists, insulin antibodies and insulin resistance. Amer. J. Med. 25, 155-159 (1958)

5. Berson, S.A., Yalow, R.S.: Quantitative aspects of the reaction between insulin and insulin-binding antibody. J. clin. Invest. 38, 1996-2016 (1959)

6. Berson, S.A., Valow, R.S.: The present status of insulin antagonists in plasma. Diabetes 13, 247-259 (1964) 
7. Berson, S.A., Yalow, R.S., Bauman, A., Rothschild, M. A., Newerly, K. : Insulin- ${ }^{131}$ metabolism in human subjects: demonstration of insulin binding globulin in the concentration of insulin treated subjects. J. clin. Invest. 35, 170-190 (1956)

8. Horino, M., Yu, S.Y., Blumenthal, H.T.: Studies on experimental insulin immunity. I. Dynamics of insulin immunity in the guinea pig. Diabetes 15, $812-822(1966)$

9. Izzo, J.L., Bartlett, J.W., Roncone, A., Izzo, M.J., Bale, W.F.: Physiological processes and dynamics in the disposition of small and large doses of biologically active and inactive ${ }^{131}$ I-insulins in the rat. J. biol. Chem. 242, 2343-2355 (1967)

10. Maggi, V., Franks, L.M., Wilson, P.D., Carbonell, A. W.: Localization of insulin in mouse tissues using fuorescence microscopy and light-microscope and high resoltuion autoradiography. Diabetologia $\mathbf{5}$, $67-68(1969)$

11. Makulu, D.R., Vichick, D., Wright, P.H., Sussman, K.E., Yu, P.L.: Insulin immunoassay by backtitration using alcohol precipitation of insulin antibody complexes. Diabetes 18,660 - 669 (1969)

12. Mannik, M., Arend, W., Hall, A., Gilliland, B.: Studies of antig'en-antibody complexes. I. Elimination of soluble complexes from rabbit circulation. J. exp. Med. 33, 713-739 (1971)

13. Masouredis, S.P., Melcher, L.R.: Blood, plasma and "Globulin" space of guinea pigs determined with $\mathrm{I}^{131}$ rabbit globulin. Proc. Soc. exp. Biol. (N.Y.) 78, $264-266$ (1951)

14. Pekar, A.H., Frank, B.H.: Conformation of proinsulin. A comparison of insulin and proinsulin self. association at neutral pH. Biochemistry 11, 4013$4016(1972)$

15. Pope, C.G.: The immunology of insulin. Advances Immunol. 5, 209-244 (1966)
16. Rubenstein, A.H., Spitz, I.: Role of the kidney in insulin metabolism and excretion. Diabetes 17, 161169 (1968)

17. Snedecor, G. W., Cochran, W.G.: Statistical Methods. Iowa State University Press 1967

18. Stein, O., Gross, J.: The localization and metabolism of $I^{131}$ insulin in the muscle and some other tissues of the rat. Endocrinology 65, 707-716 (1959)

19. Welsh, G.W., Henley, E.H., Williams, R.H., Cox, R.W.: Insulin $\mathbf{I}^{131}$ metabolism in man. Amer. J. Med. 21, 324-338 (1956)

20. Worthington, W.C., Jones, D.J., Buse, M. G.: autoradiographic study of insulin distribution in the rat with special reference to elastic tissue. Endocrinology 74, 914-924 (1964)

21. Wright, P.H., Makulu, D.R., Malaisse, W.J., Roberts, N.M., Yu, P.Y.: A method for the immunoassay of insulin. Diabetes 17, 537-546 (1968)

22. Wright, P.H., Makulu, D.R., Posey, I.J.: Guinea pig anti-insulin serum; adjuvant effect of $H$. pertussis vaccine. Diabetes 17, 513-516 (1968)

23. Wright, P.H., Rivera-Calimlim, L., Malaisse, W.J.: Endogenous insulin secretion in the rat following injection of anti-insulin serum. Amer. J. Physiol. 211, $1089-1094$ (1966)

24. Zaharko, D.S., Beck, I.V., Blankenbaker, R.: Role of the kidney in the disposal of radioiodinated and non-radioiodinated insulin in dogs. Diabetes $\mathbf{1 5}$, $680-685(1966)$

Professor P.H. Wright, M.D. Indiana University School of Medicine 1100 West Michigan Street Indianapolis, Indiana 46202 USA 